\title{
Faktor-faktor yang mempengaruhi pendapatan usaha ternak sapi di desa Kanonang Raya kabupaten Minahasa
}

\author{
G. Warangkiran, M. A.V. Manese*, N. M. Santa, B. Rorimpandey \\ Fakultas Peternakan Universitas Sam Ratulangi Manado 95115 \\ *Korespondensi (corresponding author): merry-manese@ unsrat.ac.id
}

\begin{abstract}
ABSTRAK
Tujuannya penelitian yaitu untuk menganalisis pengaruh faktor jumlah ternak sapi, biaya pakan, dan biaya tenaga kerja terhadap pendapatan usaha ternak sapi di Desa Kanonang Raya. Metode penelitian yang digunakan adalah metode survey dengan menggunakan pendekatan metode penentuan sampel berdasarkan dua tahap, yaitu pertama penentuan desa secara purposive samplingdan penentuan responden sebagai sampel secara random sampling terhadap 339 petani peternak sapi menggunakan metode slovin, sehingga jumlah sampel reponden sebanyak 77 peternak sapi di Desa Kanonang Raya.Hasil penelitian diperoleh bahwa Faktor-faktor yang berpengaruh terhadap pendapatan usaha ternak sapi adalah jumlah kepemilikan ternak, biaya pakan, dan biaya tenaga kerja.Usahaternak sapi mampu memberikan pendapatan sebesar Rp11.387.977 per tahun dengan kepemilikan ternak sapi rata-rata yaitu 3 ekor/peternak.
\end{abstract}

Kata kunci: biaya pakan, biaya tenaga kerja, pendapatan, ternak sapi

\begin{abstract}
FACTORS INFLUENCE INCOME OF CATTLE FARMING IN KANONANG RAYA VILLAGE MINAHASA REGENCY. The aim of this research was to analyzed the effect of the number of cattle, feed costs and labor costs on the income of cattle farming in Kanonang Raya Village. The research method used was a survey method using a sampling method approach based on two stages, namely the first determination of the village by purposive sampling and the determination of respondents as a sample by random sampling of 339 farmers using slovin method, so that the number of respondents was 77 farmers in Kanonang Raya Village. The results showed that the factors that influence the income of the cattle business are the number of cattle, feed costs, and labor costs. Cattle farming were able to provide income of IDR 11,387,977 per year with an average of 3 cows per farmer.
\end{abstract}

Keywords: cattle farming, feed cost, income, labor cost, 


\section{PENDAHULUAN}

Peternakan sapi merupakan salah satu bidang usaha pertanian yang banyak diusahakan oleh masyarakat pedesaan. Ternak sapi berfungsi sebagai penghasil bahan pangan sumber protein bagi masyarakat, juga sebagai tabungan bagi peternak. Pengembangan peternakan sapi di daerah pedesaan terus menerus di dorong oleh pemerintah melalui berbagai kebijakan dan strategi yang ada (Malotes, 2016; Purnomo et al., 2017; Priyanto, 2011; Suresti dan Wati, 2012; Susanti et al., 2014).

Berdasarkan hasil prasurvey Desa KanonangRaya memiliki potensi pengembangan peternakan sapi dilihat dari ketersediaan potensi lahan sebagai sumber hijauan meliputi lahan pertanian dan perkebunan maupun lahan sawah serta lahan yang tidak/belum dimanfaatkan. Berdasarkan letak geografis, Desa Kanonang raya berada di antara dua wilayah pemerintahan yang berbeda yaitu Kecamatan Kawangkoan Barat dan Kawangkoan Induk. Desa Kanonang Raya terdiri atas Desa Kanonang I, II, IV, dan V, berlokasi di Kecamatan Kawangkoan Barat, dan Desa Kanonang III, berlokasi di Kecamatan Kawangkoan Induk, Kabupaten Minahasa Provinsi Sulawesi Utara.

Permasalahannya, potensi yang dimiliki Desa Kanonang Raya, belum sepenuhnya digunakan oleh peternak sapi. Terdapat rumput letup yang merupakan kearifan lokal hijauan makanan ternak yang tersedia secara alamiah di Desa Kanonang raya. Peternak hanya menggunakan rumput yang tersedia di ladang perkebunan tanpa menanam rumput tersebut, sehingga sering terjadi kekurangan pakan mengakibatkan peternak harus membeli hijauan yang disebut palango (tanaman jagung yang masih muda, terdiri dari batang, daun dan buah) untuk memenuhi kebutuhan ternak sapi. Tentu saja kegiatan tersebut menambah biaya pakan ternak sapi.
Selanjutnya, tenaga kerja pada usaha ternak sapi adalah peternak itu sendiri. Ternak sapi umumnya hanya ditinggalkan di lahan perkebunan milik peternak, sehingga hanya peternak mencurahkan waktu kerjanya hanya beberapa waktu saja untuk mengontrol ternaknya yang tergantung pada jumlah kepemilikan ternak sapi. Rata-rata peternak memelihara 2-3 ekor ternak sapi, sehingga usaha ternak sapi tergolong usaha sampingan berdasarkan jumlah waktu kerjanya. Beberapa faktor tersebut diduga berpengaruh terhadap pendapatan usaha ternak sapi di Desa KanonangRaya.

Penelitian tentang faktor-faktor yang mempengaruhi pendapatan usaha ternak sapi di Desa Kanonang Raya berbeda dengan beberapa penelitian sebelumnya (Indratmi et al., 2018; Kalangi et al., 2014; Mirah et al., 2015; Satiti et al., 2017; Suhaemaet al.,2014. Sulistyati et al., 2013; Supartini dan Darmawan, 2014; Zuman et al., 2012).

Penelitian yang dilakukan berbeda dengan penelitian sebelumnya, lebih khusus pada lokasi penelitian yang memiliki kearifan lokal seperti ketersediaan pakan hijauan berupa rumput letup yang tidak dimiliki oleh daerah lain di Sulawesi Utara, serta memiliki lokasi tempat permandiandan air minum bagi ternak sapi (airnya mengandung belerang).Tujuan penelitian ini yaitu untuk menganalisis pengaruh faktor jumlah ternak sapi, biaya pakan, dan biaya tenaga kerja terhadap pendapatan usaha ternak sapi di Desa Kanonang Raya

\section{METODE PENELITIAN}

\section{Tempat dan waktu penelitian}

Penelitian ini dilaksanakan di Kabupaten Minahasa Kecamatan Kawangkoan Barat dan Kecamatan Kawangkoan khususnya Desa Kanonang Raya yang berlangsung selama 1 (satu) bulan yaitu tanggal 16 September - 17 Oktober 2020. 


\section{Jenis dan sumber data}

Dalam penelitian ini menggunakan jenis data primer dan sekunder, baik data kualitatif maupun data kuantitaif. Data primer adalah suatu data yang diperoleh dari wawancara dan pengamatan langsung pada peternak sapi sebagai responden, sedangkan data sekunder merupakan data yang diperoleh dari berbagai sumber, baik dari pemerintah desa maupun data statistik kecamatan dan kabupaten serta bersumer dari buku atau hasil publikasi yang dapat dipertanggung jawabkan.

\section{Metode penentuan sampel}

Penentuan sampel penelitian berdasarkan 2 tahapan, yaitu tahap pertama adalah penentuan desa sampel menggunakan metode purposive sampling atau secara sengaja dengan pertimbangan (Silalahi, 2015). Adapun yang menjadi pertimbangan ialah (1) sebagai salah satu sentra populasi ternak sapi di Kabupaten Minahasa; (2) desa yang memiliki daya dukung lahan sebagai sumber hijauan ternak sapi serta memiliki air minum dan tempat pemadian ternak sapi yang unik (mengandung belerang).Berdasarkan pertimbangan tersebut, maka Desa Kanonang Raya terpilih sebagai desa sampel. Desa kanong raya terdiri dari Desa Kanonang I, II, IV dan $\mathrm{V}$ berada di Kecamatan Kawangkoan Baratsedangkan Desa Kanonang III berada di Kecamatan Kawangkoan.

Tahapan kedua yaitu penentuan responden sebagai sampel menggunakan metode random sampling atau metode acak sederhana terhadap 339 petani peternak sapi yang berada di Desa Kanonang Raya.

Adapun jumlah sampel ditentukan menggunakan rumus Slovin (Silalahi, 2015) sebagai berikut.

Keterangan:

$$
n=\frac{N}{1+N(e)^{2}}
$$

$\mathrm{N}$ adalah jumlah populasi, $\mathrm{n}$ adalah jumlah sampel

e adalah tingkat kesalahan dalam pengambilan sampel (10\%).

Berdasarkan rumus Slovin tersebut, diperoleh jumlah sampel peternak sapi sebagai respondensebanyak 77 orang. Untuk memperoleh sampel petai peternak sapi di masing-masing desa didapat dari jumlah sampel keseluruhan dibahagi dengan populasi dikalikan 100\%, hasil tersebut dikalikan dengan populasi di desa masing-masing dibahagi 100. Dengan demikian diperoleh jumlah sampel seperti yang tampak pada Tabel 1.

\section{Analisis data}

Model analisis data menggunakan analisis matematik (Gunawan, 2020 dan Sujarwo, 2019).Analisis datafaktor-faktor yang berpengaruh terhadap pendapatan usaha ternak sapi, menggunakan pendekatan analisis regresi berganada (multiple regresion) dengan persamaan matematik sebagai berikut:

Keterangan :

$$
\mathrm{Y}=\mathrm{b}_{0}+\mathrm{b}_{1} \mathrm{X}_{1}+\mathrm{b}_{2} \mathrm{X}_{2}+\mathrm{b}_{3} \mathrm{X}_{3}+\mathrm{e}
$$

$\mathrm{Y}=$ pendapatan usaha ternak sapi (rupiah/tahun)

$\mathrm{X} 1=$ jumlah ternak sapi (ekor)

$\mathrm{X} 2$ = biaya pakan (rupiah/tahun)

Tabel 1. Jumlah Populasi dan Sampel Peternak Sapi

\begin{tabular}{clcc}
\hline No & Desa & Jumlah Populasi & Jumlah Sampel (n) \\
\hline 1 & Kanonang I & 48 & 11 \\
2 & Kanonang II & 87 & 20 \\
3 & Kanonang III & 101 & 23 \\
4 & Kanonang IV & 64 & 15 \\
5 & Kanonang V & 39 & 9 \\
\hline & Jumlah & 339 & 77 \\
\hline
\end{tabular}


$\mathrm{X} 3$ = biaya tenaga kerja (rupiah/tahun)

\section{HASIL DAN PEMBAHASAN}

\section{Karakteristik responden}

Karakteristik responden dijelaskan berdasarkan umur peternak, tingkat pendidikan, dan pengalaman beternak, dijelaskan pada Tabel2berikut.Berdasarkan UU No 13 tahun 2003 tentang tenaga kerja, diketahui bahwa umur produktif petani berkisar antara 18-64 tahun. Apabila dibandingkan dengan karakteristik umur peternak sapi pada Tabel2maka terdapat 96,11\% peternak yang termasuk kategori umur produktif. Keadaan tersebut mengartikan bahwa peternak sapi di Desa Kanonang Raya memiliki kinerja yang tinggi dalam menjalankan usaha ternak sapi.Dengan pengalaman yang cukup lama peternak akan lebih mengerti terhadap usaha yang dikelolanya dan peternak akan lebih mengerti bagaimana cara memelihara ternak untuk mendapatkan hasil yang lebih baik (Kalangi et al., 2014).

Tingkat pendidikan peternak sapi di Desa Kanonang Raya bervariasi antara tamatan SD, SMP dan SMA. Tingkat pendidikan peternak berdasarkan Tabel 2termasuk jenjang pendidikan formal berdasarkan UU Nomor 20 Tahun 2003 tentang Sistim Pendidikan Nasional yang tinggi. Tingkat pendidikan berkaitan dengan tingkat keterampilan yang dimiliki seseorang, meskipun keterampilan seseorang dapat diperoleh melalui pendidikan informal. Peternak dengan tingkat pendidikan seperti yang dijelaskan pada Tabel2 menginformasikan bahwa peternak mampu menerima dan menerapkan informasi dan teknologi yang dapat diperoleh melalui media elektronik maupun media massa terkait budidaya ternak sapi.

Pengalaman beternak peternak sapi di Desa Kanonang Raya memiliki rata-rata 15 tahun, sepertidijelaskan pada Tabel 2. Pengalaman memelihara ternak sapi merupakan salah satu faktor internal yang pengaruh terhadap produktifitas usaha pemelihara ternak sapi. Keterkaitan pengalaman memelihara ternak sapi tidak lepas dari keberadaan usaha ternak sapi yang sifatnya turun temurun dari keluarga yang satu kepada keluarga yang lainya atau dari orang tua kepada anak-anaknya. Dampak dari hal tersebut bahwa, walaupun pengalaman memelihara cukup lama tetapi karena lingkungan usaha yang turun temurun (tradisional) dan usaha yang sifatnya mewarisi tradisi/budaya yang berkembang, maka produktivitas usahanya rendah sehingah output (produksi) yang dihasilkan juga rendah.

Tabel 2. Karakteristik Responden

\begin{tabular}{|c|c|c|c|}
\hline No & Keterangan & Jumlah (Orang) & Persentase (\%) \\
\hline \multicolumn{4}{|c|}{ Umur (tahun) } \\
\hline & $31-64$ & 74 & 96,11 \\
\hline & $>64$ & 3 & 3,89 \\
\hline \multicolumn{4}{|c|}{ Tingkat Pendidikan } \\
\hline & Tamat SD & 4 & 5,19 \\
\hline & Tamat SMP & 12 & 15,58 \\
\hline & Tamat SMA & 54 & 77,12 \\
\hline & S1 & 7 & 9,09 \\
\hline \multicolumn{4}{|c|}{ Pengalaman Beternak (tahun) } \\
\hline & $5-15$ & 60 & 77,92 \\
\hline & $>15$ & 17 & 22,08 \\
\hline
\end{tabular}

terdiri dari pendidikan dasar, pendidikan menengah dan pendidikan
Faktor-faktor yang mempengaruhi pendapatan usaha ternak sapi 
Hasil analisis regresi faktor-faktor yang mempengaruhi pendapatan usahatani ternak sapi, dimana variabel bebas yaitu jumlah ternak sapi, biaya pakan dan biaya tenaga kerja, dijelaskan pada Tabel 3 berikut.

Berdasarkan hasil analisis regresi pada Tabel 3 diketahui bahwa nilai $\mathrm{R}^{2}$ persamaan sebesar $0,85 \%$ (lampiran 2) artinya variasi variabel jumlah ternak sapi $\left(\mathrm{X}_{1}\right)$, biaya pakan $\left(\mathrm{X}_{2}\right)$, dan biaya tenaga kerja $\left(\mathrm{X}_{3}\right)$ dapat menjelaskan variasi variabel pendapatan $(\mathrm{Y})$ sebesar $85,86 \%$, dan selebihnya yaitu sebesar $14,14 \%$ dijelaskan oleh variasi variabel lain di luar model. Hasil perhitungan terhadap nilai Fhitung yaitu 125,55 menunjukkan angka lebih besar dari nilai F-tabel artinya variabel jumlah ternak sapi $\left(\mathrm{X}_{1}\right)$, biaya pakan $\left(\mathrm{X}_{2}\right)$, dan biaya tenaga kerja $\left(\mathrm{X}_{3}\right)$, berpengaruh nyata terhadap variabel pendapatan (Y). Berdasarkan hasil pengujian multikolinearitas dan autokorelasidiketahui bahwa persamaan regresi yang digunakan sudah bebas dari penyimpangan asumsi klasik.

Faktor-faktor yang mempengaruhi pendapatan usaha ternak sapi di Desa Kanonang Raya dijelaskan sebagai berikut.

\section{Jumlah ternak}

Variabel jumlah ternak sapi berpengaruh sangat nyata terhadap pendapatan $(\mathrm{P}<0,001)$ dengan koefisien regresi yaitu 11.387.977. Koefisien regresi dan sesuai dengan tanda harapan, artinya setiap pertambahan jumlah ternak sapi sebesar 1 ekor, maka peternak akan menerima peningkatan pendapatan sebesar Rp11.387.977. Keadaan tersebut sejalan dengan hasil penelitian Aiba et al..(2018) dan Kalangi et al. (2014) bahwasetiap penambahan jumlah ternak yang dipelihara, maka pendapatan usaha ternak sapi akan meningkat

\section{Biaya tenaga Kerja}

Variabel biaya tenaga kerja berpengaruh nyata terhadap pendapatan $(\mathrm{P}<0,05)$ dengan koefisien regresi yaitu 1,441362 . Koefisien regresi variabel biaya tenaga kerja bernilai negatif dan sesuai dengan tanda harapan, artinya setiap pertambahan biaya tenaga kerja sebesar Rp100.000/HOK, maka peternak akan mengalamai penurunan pendapatan sebesar Rp144.136. Keadaan tersebut sejalan dengan hasil penelitian Ervina et al. (2019) bahwa biaya tenaga kerja berpengaruh negatif terhadap pendapatan usaha ternak sapi.

Pemilik ternak sapi di Desa Kanonang Raya menggunakan tenaga kerja untuk memelihara ternak sapi, khususnya pada kegiatan menggiring ternak sapi ke lokasi padang penggembalaan. Ketersediaan hijauan pada padang penggembalaan di tempat tertentu jumlahnya berkurang, sehingga pekerja harus memindahkan ternak sapi dan

Tabel 3. Hasil Analisis Regresi Faktor-faktor yang Mempengaruhi Pendapatan Usaha Ternak Sapi

\begin{tabular}{lcr}
\hline \multicolumn{1}{c}{ Variabel } & Tanda Harapan & Koefisien \\
\hline Konstanta & & 1.798 .819 \\
Jumlah ternak sapi & + & $11.387 .977^{* * *}$ \\
Biaya Pakan & - & $-0,11$ \\
Biaya Tenaga Kerja & - & $-1,44^{* *}$ \\
\hline R-squared & & 0,85 \\
F-hitung & & 125,55 \\
DW & & 1,88 \\
\hline
\end{tabular}

Keterangan : $\left.{ }^{* * *}\right)$ sangat nyata signifikan pada $\alpha=1 \%$

variabel jumlah ternak sapi bernilai positif

memilih lokasi yang menyediakan lebih 
banyak hijauan. Pemilik ternak sapi tidak membayar tenaga kerja sebagai upah, melainkan dalam bentuk anak sapiyang dilahirkan pertama kalisejak ternak sapi dipelihara. Tahun berikutnya, apabila ternak sapi tersebut kembali beranak, maka anak sapi yang dilahirkan ke dua menjadi milik peternak. Kegiatan ini dilakukan begitu seterusnya, jika induk beranak dan induk tetap menjadi milik peternak.

Usaha ternak sapi secara umum menggunakan tenaga kerja dalam keluarga. Keadaan tersebut sejalan dengan penelitian sebelumnya (Indratmi et al., 2018; Mirah et al., 2015; Satiti et al., 2017; Suhaema et al.,2014. Sulistyati et al.,2013; Supartini dan Darmawan ,2014), bahwa ayah atau kepala keluarga merupakan salah satu penyedia tenaga kerja pada usaha ternak sapi.

\section{Biaya Pakan}

Variabel biaya pakan berpengaruh tidak nyata terhadap pendapatan $(\mathrm{P}>0,1)$, namun memiliki koefisien regresi yang bernilai negatif dan sesuai dengan tanda harapan. Keadaan tersebut berarti bahwa setiap pertambahan biaya pakan, maka maka peternak akan mengalami penurunan pendapatan. Keadaan tersebut sejalan dengan Rahayu (2013) bahwa biaya pakan tidak berpengaruh nyata terhadap pendapatan usaha ternak sapi namun memiliki hubungan yang negatif, yaitu peningkatan biaya pakan akan menurunkan jumlah pendapatan usaha ternak sapi.

Ketersediaan pakan hijauan sangat berpengaruh terhadap produksi ternak sapi. Keadaan tersebut sejalan dengan penelitian sebelumnyabahwa pakan memegang peran penting pada usaha ternak sapi.

(Aibaet al.,2018; Armunanto et al.,2014; Hastang dan Asnawi, 2014)

\section{KESIMPULAN}

Usaha ternak sapi merupakan kearifan lokal di Desa Kanonang Raya dengan model pemeliharaan sesuai dengan budaya masyarakat. Usaha ternak sapi mampu memberikan pendapatan sebesar Rp11.387.977 per tahun dengan kepemilikan ternak sapi rata-rata yaitu 3 ekor/peternak.Faktor-faktor yang berpengaruh terhadap pendapatan usaha ternak sapi adalah jumlah kepemilikan ternak, biaya pakan, dan biaya tenaga kerja.

\section{DAFTAR PUSTAKA}

Aiba, A., J. C. Loing., B. Rorimpandey., dan L. S. Kalangi. 2018. Analisis pendapatan usaha peternak sapi potong di kecamatan weda selatan kabupaten halmahera tengah. Jurnal Zootek. 38(1):149-159.

Armunanto, J. Yusri., dan Cepriadi. 2014. Analisis usaha sapi potong dengan pola kemitraan antara investor (pemodal) dengan petani peternak (penggaduh) di kelurahan sail kecamatan tenayan raya kota pekanbaru. Jom Faperta. 1(2):12-23.

Ervina, D. A. Setiadi., dan T. Ekowati. 2019.Analisis faktor-faktor yang mempengaruhi pendapatan usaha ternak sapi perah kelompok tani ternak rejeki lumintu di kelurahan sumurrejo kecamatan gunungpati semarang. SOCA. 13(2):187-200.

Gunawan, C. 2020. Mahir menguasai SPSS Panduan Praktis Mengolah Data Penelitian New Edition. Yogyakarta : Deepublish.

Hastang., dan A. Asnawi. 2014. Analisis keuntungan peternak sapi potong berbasis peternakan rakyat di kabupaten bone. JIIP. 1(1):240-252

Indratmi, D., L. Zalizar., K. Khotimah., A. Septiana., N. Dwi., dan Puspitasari. 2018. Profil peternak sapi perah di wilayah desa kemiri kecamatan jabung kabupaten malang. Jurnal Aplikasi Sains dan Teknologi. 2(1):29-34

Kalangi, L.S., Y.Syaukat, S.U. Kuntjoro., dan A. Priyanti. 2014. The characteristics of cattle farmer households and the income of cattle farming businesses in east java. 
IOSR Journal of Agriculture and Veterinary Science. 7(4):29-34.

Malotes, J. 2016. Strategi pengembangan usaha peternakan sapi potong di kecamatan tinangkung utara kabupaten banggai kepulauan. J. Agroland. 23(3):198-207.

Mirah, R. E., E.K.M. Endoh., J. Pandey., dan A.H.S. Salendu, 2015. Potensi pengembangan ternak sapi pada usaha tani di kecamatan tareran minahasa. Jurnal Zootek. 35(1):4654.

Purnomo, S.H., E.T. Rahayu., dan S. B. Antoro. 2017. Strategi Pengembangan peternakan sapi potong rakyat kecamatan wuryantoro kabupaten wonogiri. Buletin Peternakan. 41(4) 484-494.

Priyanto, D. 2011. Strategi pengembangan usaha ternak sapi potong dalam mendukung program swasembada daging sapi dan kerbau tahun 2014. Jurnal Litbang Pertanian. 30:108116.

Rahayu, E.T. 2013. Analisis pendapatan usaha ternak sapi perah di kecamatan cepogo kabupaten boyolali. Sains Peternakan. 11(2) 99-105.

Satiti, R., D.A.H. Lestari., dan A. Suryani. 2017. Sistem agribisnis dan kemitraan usaha penggemukan sapi potong di koperasi gunung madu. JIIA. 5(4):34-351.

Silalahi, U. 2015. Metode Penelitian Sosial Kuantitatif. Refika Aditama. Bandung.

Suhaema, E., Widiatmaka., dan B. Tjahjono. 2014. Pengembangan wilayah peternakan sapi potong berbasis kesesuaian fisik lingkungan dan kesesuaian lahan untuk pakan di kabupaten cianjur. J. Tanah Lingk. 16(2):53-60.

Sujarwo. 2019. EkonomiProduksi: Teori dan Aplikasi. CetakanPertamaJuli 2019, UB Press. Malang.

Sulistyati, M., Hermawan., dan A. Fitriani. 2013. Potensi usaha peternakan sapi perah rakyat dalam menghadapi pasar global. Jurnal Ilmu Ternak. 13(1):17-23.

Supartini, N., dan H. Darmawan. 2014. Profil genetik dan peternak sapi peranakan ongole sebagai strategi dasar pengembangan desa pusat bibit ternak. Buana Sains. 14(1):71-84.

Suresti, A., dan R. Wati. 2012. Strategi pengembangan usaha peternakan sapi potong di kabupaten pesisir selatan. Jurnal Peternakan Indonesia. 14(1):249-262.

Susanti, Y., D. S. Priyarsono., dan S. Mulatsih. 2014. Pengembangan peternakan sapi potong untuk peningkatan perekonomian provinsi jawa tengah: suatu pendekatan perencanaan wilayah. Jurnal Agribisnis Indonesia. 2(2): 177-190.

Zuman, H., J. Setianto., dan S.P. Utama. 2012. Keputusan peternak mempertahankan sapi lokal sebagai usaha ternak di kabupaten kaur (studi kasus di desa sekunyit dan desa pasar lama, kecamatan kaur selatan). Jurnal Naturalis, Penelitian dan Pengelolaan Sumber Daya Alam dan Lingkungan. 1(2): 135-140. 